International Journal of Engineering \& Technology, $7(4.38)(2018) 773-777$
SPC
Website: $w w w . s c i e n c e p u b c o . c o m / i n d e x . p h p / I J E T$
Research paper

\title{
Assets Misappropriation in the Malaysian Public and Private Sectors
}

\author{
I.K. Norziaton ${ }^{1}$, M.D. Mohamad Ridhuan² ${ }^{2}$ A.N. Nur Adura ${ }^{3}$ \\ 1,2,3Faculty of Accountancy, Universiti Technologi MARA, Puncak Alam, Selangor, Malaysia
}

\begin{abstract}
Assets misappropriation is becoming a major concern in organizations. Over the years, the Malaysian Auditor General has reported high occurrences of assets misappropriation at the federal, state and even local governments. It is surprising that not only assets misappropriation is a major concern in the public sector but also has indicated that it is a common sight in all organizations. The current trend is rather disconcerting because employees are accountable to perform their jobs at the interest of the organizations. Various researches in the past found that the incidence of assets misappropriation occurs when employees used the official vehicles, internet connection, computers, stationery and facilities for personal and family benefits. The issue of assets misappropriation has been increasing and is the highest among other types of frauds. Even though the issue seems to be trivial, yet, if it is left untreated, the symptom will become an incurable disease that it will cause major leakages to the organizations. Hence, this paper highlights the common practices and issues of assets misappropriation in public and private organizations. It also discusses why the acts of assets misappropriation occur. The paper concludes that to promote awareness of the public and private sectors employees is vital in the issues of assets misappropriation.
\end{abstract}

Keywords: Assets Misappropriation, Employees, Fraud, Private Sector, Public Sector

\section{Introduction}

Fraud is one of the world's most challenging issues and has become a great pressure in the world economy. The rise of fraud in Malaysia continues to be a major problem for organizations and its impact on reputation and financial health can be enormous. This is consistent with the survey conducted by the Association of Certified Fraud Examiners (ACFE) ${ }^{3}$ whereby certified fraud examiners estimate that organizations lose an average of $5 \%$ of revenues in a given year as a result of fraud. Under the Malaysia economic landscape, it was reported in the PwC Global Economic Crime Survey $^{18}$ that $13 \%$ of Malaysian victims experienced financial losses in excess of USD1 million.

Fraud occurs in private sector as well as public sector; from the smallest local firm to the largest multi-national conglomerate or government agencies ${ }^{20}$. Former Auditor General of Malaysia in the International Conference Dealing with Public Sector Fraud: Enhancing Integrity and Transparency in Government Financial Market $t^{5}$ makes a point that fraud and corruption are omnipresent and it is not confined to the third world countries only.

Fraud cases also happened in developed countries such as Enron, WorldCom and Satyam in USA, Banco Ambrosiano in Italy, Barrings in UK and Toshiba in Japan. Malaysia too has its fair share with numerous cases of fraud happening in the past decades. Revelations of fraud and misconduct in the private and public sectors, such as Transmile, Port Klang Free Zone, National Feedlot Corporation and recently the graft probe involving the Felda Global Ventures Holdings Berhad has pose a constant threat to the regulatory structure, public trust and confidence in capital market.

According to the PwC Global Economic Crime Survey ${ }^{18}$ the types of economic crime experienced is led by assets misappropriation even though the percentage showed a slightly decrease over the years of 2014 from $69 \%$ to $64 \%$ in year 2016. Those economic crimes such as assets misappropriation, procurement fraud, corruption and bribery, cybercrime and accounting fraud are considered as the most common crimes that occurred in Malaysia. Assets misappropriation is the most common economic crime experienced by organizations with $69 \%$ of respondents are suffering from it. Consistent with the ACFE report ${ }^{3}$ assets misappropriation is the most common type of occupational fraud and was reported arising in more than $83 \%$ of the total cases.

Over the years, Audit Report by the Auditor General of Malaysia revealed high incidences of assets misappropriation at the federal, state and even local governments. For instance, the Audit Report ${ }^{4}$ exposed that more than three hundred items amounted to RM1.3 million were reported as missing. Such cases have resulted in wastage of resources and have reduced economic growth and the quality of life, undermined government credibility and reduced its effectiveness ${ }^{6}$. Assets misappropriation is not a simple theft but it covers across-the board acts that resulted in the employee's personal benefits towards the organization's losses ${ }^{18}$. The longer the assets misappropriation last, the more destructive effect on the finance of an organization would $\mathrm{be}^{8}$. A study on Malaysian local authorities has shown that assets misappropriation is a major concern in the public sector and also has indicated that it is a common sight in other organizations ${ }^{1}$. Even though the impact might not be significant, but, if it is left untreated, the symptom will turn into an incurable disease. At the end of result, the trivial instalments will make tremendous impact on the financial waste due to the unnecessary expenditure incurred. A lot can be saved from the loss caused from fraud if it is prevented, providing resources that can be reinvested in building the economy and society at large.

Based on the arguments and critical importance of this issue, the aims of this study is to examine the employee's awareness and the 
common practices of assets misappropriation in private and public sectors. It is hope that this study provides empirical evidence to the organizations to offer certain highlights on the unethical conduct by the employees. Thus, appropriate prevention measures can be made in order to curb the above situations so that the losses can be reduced.

\section{Literature review}

The Association of Certified Fraud Examiners (ACFE) defined 'occupational fraud' as "the use of one's occupation for personal enrichment through the deliberate misuse or misapplication of the employing organization's resources or assets". The three main categories of occupational fraud are assets misappropriation, corruption, and financial statement fraud. Hence, assets misappropriation is one of the branches of occupational fraud. It includes those frauds in which a perpetrator employs trickery or deceit to steal or misuse of organization's resources ${ }^{2}$. According to the KPMG Malaysia Report ${ }^{13}$, there are three types of frauds in the government sector; assets misappropriation, corruptions and breach of trust. The incidence of assets misappropriation occurs when the government officers used the official vehicles, computers and facilities for personal interest and family benefits ${ }^{7}$. Assets misappropriation covers from small misuse of stationeries to the misuse of official vehicles ${ }^{16}$.

The results from KPMG Forensics Integrity Survey ${ }^{12}$ found that $74 \%$ of the respondents agreed that they had personally observed or had first-hand knowledge of wrongdoings within their organization. Misappropriation of government assets are easy to detect but proved hard to prevent probably because of the prevalent cultures surrounding the organization. In another separate study ${ }^{11}$, majority of their respondents agreed that it is acceptable to convert an entitled business air ticket into two economy class tickets (so that the government officer could travel with his/her spouse on the government expense for free) as long as it is within the budget even though they are aware that it is unethical. In addition, assets misappropriation committed by employees is often in relatively small and immaterial amounts and it's difficult to detect ${ }^{8}$. This is due to the fact that they conceal the misappropriation in ways that are ambiguous. Even though assets misappropriation schemes tend to cause the lowest losses, they can cause lasting damage, particularly to the image and public confidence towards the management of government. As such, if the issue is not remediated, the symptom will become an incurable disease and it will lead to further leakages to the government expenditures ${ }^{16}$.

Various researches in the past have cited that organizations with weak internal controls are susceptible to fraudulent asset misappropriation schemes. A study conducted by PwC Global Economic Crime ${ }^{17}$ indicates that within government/state-owned enterprises around the world, fraud seems to be more of an internal than external phenomenon. Organizations that suffered from economic crime reported that $57 \%$ of perpetrators were internal and 37 percent were external. Accordingly, frauds are likely to take place in non-profit organization and government sector. The underlying reasons are fragile internal control, trust issue, difficulties in verifying certain revenue and expenses and vague understanding in policy and procedures of public procurement ${ }^{10}$. The presence of strong ethical environment may contribute towards lower incidence of fraud ${ }^{21}$. There are few reasons that might cause the incident of frauds to increase. Among the reasons cited for the expected increase were poor management practices, weakened social values, economic pressure, people not held responsible for their actions and inadequate training for those responsible for fraud prevention and detection.

Currently, assets misappropriation is becoming a main concern in both public and private sectors. Past study ${ }^{11}$ has concluded that the mentality of public officers is identified as the key barrier towards awareness of fraud deterrence; this is because most of the respondents are not aware or familiar with the government's policy ${ }^{9}$
Additionally, PwC Global Economic Crime ${ }^{17}$ indicates that assets misappropriation is the most common form of fraud in Malaysia where $83 \%$ of respondents stated they had suffered from assets misappropriation in the last two years. Nevertheless the incidents seem trivial, yet, if it is ignored, will become major leakage to the organizations. With the focus to curb fraud and corruption and promoting good governance in public and private sectors, the Malaysian government has put in place an elaborate set of mechanisms and strategies in order to restore public faith towards the organizations ${ }^{15}$. The government has made an enormous efforts to curb corruption and mishandling of organizations assets by setting up the Anti-Corruption Agency of Malaysia (ACA), Public Accounts Committee (PAC), National Integrity Plan (NIP) and the Integrity Institute of Malaysia (IIM), Public Bureau Complaints (PCB), and Disciplinary Board and Code of Ethics.

\section{Research method}

This study used questionnaire survey to collect information related to the assets misappropriation in private and public sectors. The questionnaire survey was adopted with some modifications to fit the context of this study ${ }^{1}$. The questionnaire comprises of 27 items that are divided into three main sections. Section A requests respondents to complete 4 items related to their demographic profile. Section B requests respondents to complete 7 items on the awareness of assets misappropriation. Section $\mathrm{C}$ requests respondents to complete 16 items related to the four different scenarios on assets misappropriation. The questionnaire used 5-point scale ranging from ' 1 ' as strongly disagree to ' 5 ' as strongly agree. The data was collected through primary data. In order to collect the data within the time frame, the questionnaire survey was administered over a four months period starting 1 April 2017 to 31 July 2017. The questionnaires were distributed to 250 employees from private and public sectors, however $173(69.2 \%)$ were returned and usable.

\section{Results and discussion}

\subsection{Demographic Profile}

This study gathered a total of 77 respondents from the public sector and 96 respondents from the private sector with female respondents dominated as the majority (59 and 66 respondents) in both sectors respectively. Majority respondents from public sector aged between 31 to 40 years old whereas the private sector ranges from 21 to 30 years old. In terms of job position, middle-level management becomes the majority (48) followed by junior level management (23) in public sector. However, junior level management (57) dominated as the majority in private sector followed by 31 respondents posted as middle-level management. This study also revealed that majority of the public sector (32) respondents has 5-10 years of working experience while most private sector respondents (62) have working experience below than 5 years.

Table 1: Demographic profile

\begin{tabular}{cccc}
\hline \multicolumn{2}{c}{ Item } & $\begin{array}{c}\text { Public } \\
\text { Sector }\end{array}$ & $\begin{array}{c}\text { Private } \\
\text { Sector }\end{array}$ \\
\hline \multirow{3}{*}{ Age of Respond- } & 21 - 25 years old & 4 & 33 \\
ent & 26 - 30 years old & 13 & 35 \\
& $31-35$ years old & 33 & 7 \\
& $36-40$ years old & 21 & 11 \\
& above 40 years old & 6 & 10 \\
\hline \multirow{2}{*}{ Gender } & Male & 18 & 30 \\
& Female & 59 & 66 \\
\multirow{2}{*}{ Working Experi- } & Below 5 years & 16 & 62 \\
ence & $5-10$ years & 32 & 15 \\
& Above 10 years & 29 & 19 \\
\hline \multirow{2}{*}{ Job Position } & Upper level management & 6 & 8 \\
& Middle level management & 48 & 31
\end{tabular}




\subsection{Awareness on Assets Misappropriation}

Table 2 demonstrates that more than half of the respondents from both sectors stated that their organization did promote awareness on assets misappropriation. Almost all of them (public sector, 74; private sector, 94) are familiar with assets misappropriation term. Despite the fact that most respondents affirmed using organization's asset as personal benefit is considered as assets misappropriation, (public sector,76; private sector, 88) ironically, there are also more than half of them had self-experience with this illegal practice (public sector, 53; private sector, 56) and witnessing the assets misappropriation conducted by their colleagues. The result also exposed majority respondents experiencing this practice more than 5 times and specified among the reason for people to involve in assets misappropriation is that they are not aware of it.

\begin{tabular}{|c|c|c|c|}
\hline \multicolumn{2}{|l|}{ Item } & $\begin{array}{l}\text { Public } \\
\text { Sector }\end{array}$ & $\begin{array}{l}\text { Private } \\
\text { Sector }\end{array}$ \\
\hline \multirow{2}{*}{$\begin{array}{c}\text { Awareness on MOA by the } \\
\text { organization }\end{array}$} & Yes & 52 & 50 \\
\hline & No & 25 & 46 \\
\hline \multirow{2}{*}{ Familiar with the term of MOA } & Yes & 74 & 93 \\
\hline & No & 3 & 3 \\
\hline \multirow{2}{*}{ Self-experience with MOA } & Yes & 53 & 56 \\
\hline & No & 24 & 40 \\
\hline \multirow{2}{*}{$\begin{array}{l}\text { Witnessing MOA conducted by } \\
\text { colleagues }\end{array}$} & Yes & 62 & 67 \\
\hline & No & 15 & 29 \\
\hline \multirow{4}{*}{ Frequent experience on MOA } & Below 5 times & 49 & 53 \\
\hline & $5-10$ times & 14 & 26 \\
\hline & $10-15$ times & 2 & 3 \\
\hline & $\begin{array}{c}\text { More than } 15 \\
\text { times }\end{array}$ & 12 & 14 \\
\hline \multirow{2}{*}{$\begin{array}{l}\text { Reason for a person involve with } \\
\text { MOA }\end{array}$} & Not aware & 54 & 61 \\
\hline & $\begin{array}{c}\text { Everybody is } \\
\text { doing it }\end{array}$ & 23 & 35 \\
\hline \multirow{2}{*}{$\begin{array}{l}\text { Using organization's asset as } \\
\text { personal benefit is considered } \\
\text { MOA }\end{array}$} & Yes & 76 & 88 \\
\hline & No & 1 & 8 \\
\hline
\end{tabular}

The following section presents the results of scenario settings of asset misappropriation in organization. There are four different scenarios used to describe the respondents' view based on four statements given.

\subsection{Scenario 1: Usage of official vehicle for personal and family benefits.}

Table 3 shows the results of scenario 1 where respondents were given the settings about the usage of official vehicle for personal and family benefits. The results revealed that majority of the public sector respondents are strongly disagreed to all statements, which outweigh the other Likert scale dimension. In particular, $32.5 \%$ respondents from public sector strongly disagreed, but most private sector respondents $(30.2 \%)$ agreed that using an official vehicle for personal advantage is a common practice in their organization.

Table 3: Scenario 1: Usage of official vehicle for personal and family benefits.

\begin{tabular}{cccc}
\hline \multicolumn{1}{c}{ Item } & & $\begin{array}{c}\text { Public } \\
\text { Sector }(\%)\end{array}$ & $\begin{array}{c}\text { Private Sec- } \\
\text { tor } \\
(\%)\end{array}$ \\
\cline { 2 - 3 } This is a common & Strongly agree & 10.4 & 16.7 \\
practice & Agree & 27.3 & 30.2 \\
& Neutral & 19.5 & 17.7 \\
& Disagree & 0.4 & 9.4 \\
& Strongly disagree & 32.5 & 26.0 \\
\hline My colleagues are & Strongly agree & 9.1 & 16.7 \\
doing the same & Agree & 19.5 & 20.8 \\
thing & Neutral & 27.3 & 28.1 \\
& Disagree & 14.3 & 11.5 \\
\hline
\end{tabular}

\begin{tabular}{cccc} 
& Strongly disagree & 29.9 & 22.9 \\
\hline \multirow{2}{*}{ I think that it is not } & Strongly agree & 1.3 & 8.3 \\
against the law or & Agree & 7.8 & 16.7 \\
organizations' & Neutral & 16.9 & 27.1 \\
policy & Disagree & 16.9 & 14.6 \\
& Strongly disagree & 57.1 & 33.3 \\
\hline & Strongly agree & 5.2 & 13.5 \\
My superior has & Agree & 9.1 & 19.8 \\
given me the per- & Neutral & 24.7 & 27.1 \\
mission to do so & Disagree & 22.1 & 11.5 \\
& Strongly disagree & 39.0 & 28.1 \\
\hline
\end{tabular}

Meanwhile, $29.9 \%$ of public sector respondents have strongly disagreed that their colleagues committing this practice whereas private sector $(28.1 \%)$ is neutral. Respondents from both sectors also expressed strongly disagreed that this scenario is not against the law or organizational policy (public sector, 57.1\%; private sector, $33.3 \%$ ). On the other hand, $39.0 \%$ of the public sector and $28.1 \%$ of private sector respondents are strongly disagreed that they obtain permission from their superior to use the official vehicle for personal and family benefits.

\subsection{Scenario 2: Usage of office's computer, printer and stationeries for personal and family benefits}

With reference to Table 4, Scenario 2 summarizes the responses gathered on the usage of office's computer, printer and stationeries for personal and family benefits. Majority of the public sector respondents representing $29.9 \%$ and $37.5 \%$ from private sector have strongly agreed that this action is regarded as a common practice. Respondents from the private and public sectors have also agreed that their colleagues are doing the same practice. Interestingly, $29.9 \%$ from public sector and $24 \%$ from private sector employees strongly disagreed that the situation was not against the law or organizations' policy but there was no action taken against them. However, $28.1 \%$ of private sector respondents strongly disagreed that they were given the permission to use office's computer, printer and stationeries for personal and family benefits where else $35.1 \%$ of the public sector respondents were unsure about the above situation.

Table 4: Scenario 2: Usage of office's computer, printer and stationeries for personal and family benefits

\begin{tabular}{|c|c|c|c|}
\hline \multicolumn{2}{|c|}{ Item } & $\begin{array}{c}\text { Public } \\
\text { Sector } \\
(\%) \\
\end{array}$ & $\begin{array}{c}\text { Private Sec- } \\
\text { tor } \\
(\%)\end{array}$ \\
\hline \multirow{5}{*}{$\begin{array}{c}\text { This is a common } \\
\text { practice }\end{array}$} & Strongly agree & $29.9 \%$ & $37.5 \%$ \\
\hline & Agree & $24.7 \%$ & $35.4 \%$ \\
\hline & Neutral & $24.7 \%$ & $12.5 \%$ \\
\hline & Disagree & $6.5 \%$ & $6.3 \%$ \\
\hline & Strongly disagree & $14.3 \%$ & $8.3 \%$ \\
\hline \multirow{5}{*}{$\begin{array}{l}\text { My colleagues are } \\
\text { doing the same } \\
\text { thing }\end{array}$} & Strongly agree & $26.0 \%$ & $36.5 \%$ \\
\hline & Agree & $31.2 \%$ & $35.4 \%$ \\
\hline & Neutral & $26.0 \%$ & $15.6 \%$ \\
\hline & Disagree & $6.5 \%$ & $3.1 \%$ \\
\hline & Strongly disagree & $10.4 \%$ & $9.4 \%$ \\
\hline \multirow{5}{*}{$\begin{array}{l}\text { I think that it is not } \\
\text { against the law or } \\
\text { organizations' } \\
\text { policy }\end{array}$} & Strongly agree & $2.6 \%$ & $14.6 \%$ \\
\hline & Agree & $7.8 \%$ & $17.7 \%$ \\
\hline & Neutral & $32.5 \%$ & $28.1 \%$ \\
\hline & Disagree & $27.3 \%$ & $15.6 \%$ \\
\hline & Strongly disagree & $29.9 \%$ & $24.0 \%$ \\
\hline \multirow{5}{*}{$\begin{array}{l}\text { My superior has } \\
\text { given me the per- } \\
\text { mission to do so }\end{array}$} & Strongly agree & $3.9 \%$ & $10.4 \%$ \\
\hline & Agree & $6.5 \%$ & $18.8 \%$ \\
\hline & Neutral & $35.1 \%$ & $27.1 \%$ \\
\hline & Disagree & $24.7 \%$ & $15.6 \%$ \\
\hline & Strongly disagree & $29.9 \%$ & $28.1 \%$ \\
\hline
\end{tabular}

\subsection{Scenario 3: Usage of office's equipment and materi-} als for private consultation and family benefits

Based on Table 5 Scenario 3, 27.3\% of the public sector respondents provide discontentment on the usage of office's equipment 
and materials for private consultation and family benefits as a common practice. This is however, in contrast to the responses gathered from the private sector respondents, where $25 \%$ are in agreement that it is a common practice and have also agreed that their colleagues are practicing the same thing too. Interestingly, both public $(42.9 \%)$ and private sectors $(31.3 \%)$ respondents agreed that this practice is against the law and organizations' policy. In addition, both sectors are also aware that their superior does not grant them permission to conduct such act (public sector, $41.6 \%$; private sector, $33.3 \%$ ).

Table 5: Scenario 3: Usage of office's computer, printer and stationeries for personal and family benefits

\begin{tabular}{llll}
\hline Item & & $\begin{array}{l}\text { Public } \\
\text { Sector } \\
(\%)\end{array}$ & $\begin{array}{l}\text { Private } \\
\text { tor } \\
(\%)\end{array}$ \\
\hline This is a common & Strongly agree & $6.5 \%$ & $16.7 \%$ \\
practice & Agree & $24.7 \%$ & $25.0 \%$ \\
& Neutral & $26.0 \%$ & $25.0 \%$ \\
& Disagree & $15.6 \%$ & $15.6 \%$ \\
& Strongly disagree & $27.3 \%$ & $17.7 \%$ \\
\hline My colleagues are & Strongly agree & $3.9 \%$ & $14.6 \%$ \\
doing the same & Agree & $27.3 \%$ & $32.3 \%$ \\
thing & Neutral & $28.6 \%$ & $26.0 \%$ \\
& Disagree & $19.5 \%$ & $12.5 \%$ \\
& Strongly disagree & $20.8 \%$ & $14.6 \%$ \\
\hline I think that it is not & Strongly agree & $0.0 \%$ & $7.3 \%$ \\
against the law or & Agree & $6.5 \%$ & $15.6 \%$ \\
organizations' & Neutral & $24.7 \%$ & $25.0 \%$ \\
policy & Disagree & $26.0 \%$ & $20.8 \%$ \\
& Strongly disagree & $42.9 \%$ & $31.3 \%$ \\
\hline My superior has & Strongly agree & $1.3 \%$ & $6.3 \%$ \\
given me the per- & Agree & $7.8 \%$ & $10.4 \%$ \\
mission to do so & Neutral & $27.3 \%$ & $26.0 \%$ \\
& Disagree & $22.1 \%$ & $24.0 \%$ \\
& Strongly disagree & $41.6 \%$ & $33.3 \%$ \\
\hline
\end{tabular}

\subsection{Scenario 4: Usage of office's utilities such as elec- tricity, water, telephone and others for personal and family benefits}

From Table 6, it can be concluded that most of the private sector respondents $(33.3 \%)$ agreed that it is a common practice in their organizations but it contradicts with the public sector $(26 \%)$ results. This is because the public sector respondents are aware that it is against the law and organizations' policy $(40.3 \%)$ and they are not been given permission to do so $(39 \%)$. Interestingly, majority of both groups agreed that their colleagues are using the office's utilities such as electricity, water, telephone and others for personal and family benefits.

Table 6: Scenario 4: Usage of office's utilities such as electricity, water, telephone and others for personal and family benefits

\begin{tabular}{cccc}
\hline \multirow{2}{*}{$\begin{array}{c}\text { Item } \\
\text { This is a common }\end{array}$} & & $\begin{array}{c}\text { Public } \\
\text { Sector } \\
(\%)\end{array}$ & $\begin{array}{c}\text { Private Sec- } \\
\text { tor } \\
(\%)\end{array}$ \\
\cline { 2 - 4 } practice & Strongly agree & $20.8 \%$ & $22.9 \%$ \\
& Agree & $22.1 \%$ & $33.3 \%$ \\
& Neutral & $22.1 \%$ & $21.9 \%$ \\
& Disagree & $9.1 \%$ & $10.4 \%$ \\
& Strongly disagree & $26.0 \%$ & $11.5 \%$ \\
\hline \multirow{3}{*}{ My colleagues are } & & & \\
doing the same & Strongly agree & $22.1 \%$ & $24.0 \%$ \\
thing & Agree & $27.3 \%$ & $33.3 \%$ \\
& Neutral & $22.1 \%$ & $19.8 \%$ \\
I think that it is not & Disagree & $9.1 \%$ & $12.5 \%$ \\
against the law or & Strongly disagree & $19.5 \%$ & $10.4 \%$ \\
organizations' & Strongly agree & $5.2 \%$ & $9.4 \%$ \\
policy & Agree & $7.8 \%$ & $18.8 \%$ \\
& Neutral & $24.7 \%$ & $33.3 \%$ \\
\hline My superior has & Disagree & $22.1 \%$ & $16.7 \%$ \\
\hline
\end{tabular}

\begin{tabular}{cccc}
\hline given me the per- & Agree & $5.2 \%$ & $10.4 \%$ \\
mission to do so & Neutral & $32.5 \%$ & $35.4 \%$ \\
& Disagree & $20.8 \%$ & $22.9 \%$ \\
& Strongly disagree & $39.0 \%$ & $21.9 \%$ \\
\hline
\end{tabular}

\section{Conclusions}

The above discussion has explained the reality of assets misappropriation in public and private sectors. As mentioned earlier, even though the issue seems to be trivial and does not really involve huge amount of losses, yet, if it is remain untreated, the symptom will cause major leakages to the organizations. Past study has indicated that the efforts to safeguard government assets might be wasted due to the absence of capable guardians since it has created a space of opportunity for fraud to happen ${ }^{11}$. Assets misappropriation could have been avoided provided the officers in charge are more vigilant, competent and practice high level of integrity in discharging their responsibilities towards the organizations. It is the responsibility of each individual employee to protect the revenues and assets of their organizations. They are mandated to act in proper manner and manage the resources efficiently. Failure to do so will cause the public to lose faith and confidence on the credibility and integrity of the management. Employees' character is considered as an important aspect that will bring down the efforts to enhance awareness of fraud among public servants. The responses are consistent with the opinion given in another study ${ }^{14}$ that employees' upbringing, culture, and ethical beliefs would determine the characters of employees into the organization. If the challenge is not properly tackled in a holistic manner, it will portray that the policies and procedures are just for ceremonial purposes.

Acknowledgments: We are gratefully acknowledging the financial support provided by Universiti Teknologi MARA (UiTM), Malaysia (Lestari Grant 600-IRMI/DANA KCM 5/3/LESTARI $(141 / 2017)$.

\section{References and Notes}

[1] b Majid, R., Mohamed, N., Haron, R., \& Bahiyah, N. (2014), Misappropriation of Assets in Local Authorities - A Challenge to Good Governance. Procedia - Social and Behavioral Sciences, 164, 345 350

[2] Albrecht, C., Kranacher, M-J., \& Albrecht, W. S. (2008), Asset Misappropriation Research White Paper for the Institute for Fraud Prevention. Retrieved from http://www.theifp. org/researchgrants/recentStudies.

[3] Association of Certified Fraud Examiners (ACFE). (2016), Report to the Nations on Occupational Fraud and Abuse. Global Fraud Study Retrieved from http://www.acfe.com/rttn2016.aspx

[4] Audits Report by the Auditor General of Malaysia. (2012). Retrieved from https://www.audit.gov.my

[5] Buang, A. (2008), How National Audit Department plays its role in mitigating fraud and enhances the public accountability in Government Financial Management System. International Conference: Dealing With Public Sector Fraud: Enhancing Integrity and Transparency In Government Financial Management

[6] Buang, A. (2010), Keynote Address "Setting the Tone for Fraud Risk Management". Corporate Fraud Conference. Kuala Lumpur

[7] Campos, J. E. and Pradhan, S. (2007). The Many Faces Of Corruption: Tracking Vulnerabilities At The Sector Level, The World Bank, Washington DC

[8] Chapple, L., Ferguson, C and Kang, D. (2007), Corporate Governance and Misappropriation. Journal of Forensic \& Investigative Accounting, 1(2), 1-26

[9] Government's policy (Rules no. 4(2)(c) of Public Officers Regulations, Conduct and Discipline 1993, Amendments 2002). www.etatatertib.jpm.gov.my

[10] Greenlee, J., Fischer, M., Gordon, T, and Keating, E. (2007). An Investigation of Fraud in Nonprofit Organizations: Occurrences and Deterrents, Nonprofit and Voluntary Sector Quarterly, 36(4), $10-18$ 
[11] Haron, R., Mohamed, N., Paino, H. (2015), Misappropriation of Assets: A decepticon of leakages in Malaysian public sector. International Conference on Accounting Studies (ICAS). Johor Bahru, Johor

[12] KPMG Forensic's Integrity Survey. (2009). Retrieved from www.kpmg.com

[13] KPMG Report Malaysia. (2011), The Common Types of Fraud, It's Causes and Impact to a Public Sector Organization. Kuching, Sarawak

[14] Murdoch, H. (2008). The Three Dimensions of Fraud. Internal Auditor, 65, 81-83.

[15] Nur Adura A.N. and I.K. Norziaton. (2017). The Development of Auditing Arena and Corporate Governance Landscape in Malaysia: An Initiative to Combat Fraud and Corruptions. SHS Web of Conference, 36(4), 1-10

[16] Orchard, L. X, Decker, L. and Kiziran, T. (2007). Wayne Manufacturing: A Teaching Case On The Detection Of Misappropriation Of Assets, Journal of College Teaching \& Learning, 4(10), 67-76

[17] PwC (2011). Global Economic Crime Survey. Retrieved from http://www.pwc.com

[18] PwC (2016). Global Economic Crime Survey. Retrieved from https://www.pwc.com/gx/en/services/advisory/forensics/economiccrime-survey.html

[19] Stewart, L. (2007), "Managing Government Employees: How to Motivate Your People, Deal with Difficult Issues and Achieve Tangible Results". New York.

[20] Tuan Mat, T. Z., Syed Mustapha Nazri, S. N. F., Mohd Fahmi, F., Ismail, A. M., \& Smith, M. (2013), Assessing the Fraud Prevention Mechanisms in Malaysian Government Agencies. Malaysian Accounting Review, 12( 2), 141-169

[21] Ziegenfuss, D.E,. (2001). The Role Of Control Environment In Reducing Local Government Fraud, Journal of Public Budgeting, Accounting \& Financial Management, 13(3), 312-314 